\title{
THE EFFECT OF INSPIRED OXYGEN CONCENTRATION ON INTRAPULMONARY RIGHT-TO-LEFT SHUNT DURING POSTOPERATIVE MECHANICAL VENTILATION
}

\author{
G. Wolff, E. Grädel, M. Rist, T. Schwab and B. Pavietic
}

SUMMARY

A consecutive series of patients undergoing cardiac surgery for valve replacement was divided into two groups. The first underwent postoperative artificial ventilation using the oxygen-driven Bird ventilator. The inspiratory oxygen concentration was $83 \%$. In the second group a Bird ventilator was also used but with an oxygen concentration of $40 \%$. In the first group the intrapulmonary right-to-left shunt rose to an average of $17 \%$ during the first two postoperative days and in the second group to an average of $9 \%$. The study supports the view that the inspiratory oxygen concentration should only be kept high enough to achieve a normal oxygen saturation of arterial blood.

Postoperative support of ventilation is now generally regarded as a valuable adjunct in the treatment of patients following open-heart surgery, particularly when cardiac output may be diminished. It further helps to prevent terminal airway collapse which is a frequent occurrence after thoracic and upper abdominal surgery. Nevertheless in a number of patients the chest X-ray may be normal in the presence of severe arterial hypoxaemia. This is the consequence of an increase in intrapulmonary rightto-left shunt.* A high inspired oxygen concentration is one of the factors which has been blamed for an increase of the intrapulmonary right-to-left shunt (Nash, Blennerhassett, and Pontoppidan, 1967). The purpose of this investigation was to compare the effect of prolonged (48-72 hours) ventilation with a high concentration of oxygen (average $83 \%$ ) and a lower one $(40 \%)$ on intrapulmonary right-toleft shunt.

\section{METHODS}

The intrapulmonary right-to-left shunt was calculated as the shunted component of cardiac output using Rahn's equation (1) (Rahn and Farhi, 1964).

$$
\mathbf{Q} / \mathbf{Q} \mathrm{T}=\left(\mathrm{Cc}_{\mathrm{O}_{2}}^{\prime}-\mathrm{Ca}_{\mathrm{O}_{2}}\right) /\left(\mathrm{Cc}_{\mathrm{O}_{2}}^{\prime}-\mathrm{C}_{\mathrm{O}_{2}}\right)
$$

\footnotetext{
Explanation of symbols:

QS=R-L shunt flow. $\quad A=$ Alveolar.

$\mathrm{QT}=$ Total cardiac output. $\quad \mathrm{c}^{\prime}=$ Pulmonary-capillary.

$\mathrm{S}=$ Oxygen saturation.

$\mathrm{C}=$ Oxygen content.

a = Arterial.

$\overline{\mathrm{v}}=$ Mixed venous.

PB = Barometric pressure.

$\overrightarrow{\mathbf{E}}=$ Mixed expired.

* This statement is only correct if there is an adequate ventilation, i.e. $\mathrm{PaCO}_{2}$ is normal and the patient is ventilated with an inspiratory oxygen concentration at least that of room air. Any cause of pulmonary venous hypoxaemia will produce arterial hypoxaemia. Our formula for calculating the shunt does not take into consideration the cause of the hypoxaemia.
}

Since arterial $\mathrm{Po}_{2}$ of our patients ventilated with $100 \%$ oxygen was always above $150 \mathrm{~mm} \mathrm{Hg}$, the arterial and therefore the pulmonary capillary blood was always fully saturated. The pulmonary capillary blood $\mathrm{Po}_{2}$ may be considered to be identical with the alveolar $\mathrm{Po}_{2}$, and was therefore calculated as

$$
\mathrm{Pc}_{\mathrm{O}_{2}}^{\prime}=\mathrm{PB}-\left(\mathrm{PA}_{\mathrm{H}_{2} \mathrm{O}}+\mathrm{Pa}_{\mathrm{CO}_{2}}\right)
$$

where alveolar $\mathrm{PcO}_{2}\left(\mathrm{PA}_{\mathrm{CO}_{2}}\right)$ is assumed to equal arterial $\mathrm{PcO}_{2}\left(\mathrm{~Pa}_{\mathrm{CO}_{2}}\right)$. This makes it possible to express equation (1) in values (2) readily measurable in patients.

$$
\begin{aligned}
& \frac{\dot{Q} S}{\dot{Q} \mathrm{~T}}=\frac{\left(\mathrm{PA}_{\mathrm{O}_{2}}-\mathrm{Pa}_{\mathrm{O}_{2}}\right) \cdot 0.0031}{\left(\mathrm{Ca}_{\mathrm{O}_{2}}-\mathrm{C}_{\mathrm{O}_{2}}\right)+\left(\mathrm{PA}_{\mathrm{O}_{2}}-\mathrm{Pa}_{\mathrm{O}_{2}}\right) \cdot 0.0031} \\
& \uparrow_{\mathrm{Ca}_{\mathrm{O}_{2}}=} \begin{array}{l}
\mathrm{C}_{\mathrm{O}_{2}}=\mathrm{Hb} \cdot 1.34 \cdot \mathrm{Sb}_{\mathrm{O}_{2}} \\
\mathrm{Cb}
\end{array}
\end{aligned}
$$

$\mathrm{Pa}_{\mathrm{O}_{2}}, \mathrm{pH}$ and $\mathrm{Pa}_{\mathrm{CO}_{2}}$ were determined with the Eschweiler electrode. The calculation of the central venous saturation from measured pulmonary arterial $\mathrm{pH}$ and $\mathrm{Po}_{2}$ values seemed too uncertain in view of recently established $\mathrm{pH}$-independent changes in the oxygen dissociation curve (Laver, 1970). The central venous saturation was measured using the American optical oximeter. The ratio of deadspace ventilation (VD) to total tidal volume (VT) was estimated by the formula (3).

$$
\mathrm{VD} / \mathrm{VT}=1-\left(\mathrm{P} \overline{\mathrm{E}}_{\mathrm{CO}_{2}} / \mathrm{Pa}_{\mathrm{CO}_{2}}\right)
$$

where $\mathrm{P} \overrightarrow{\mathrm{E}}_{\mathrm{CO}_{2}}=$ mixed expired $\mathrm{CO}_{2}$ tension after

GUNTHER WOLFF, M.D.; ERICH GRÄDEL, M.D.; MARCUS Rist, M.D.; Thomas SCHWAB, M.D.; BozIDaR Pavletic, M.D.; Department of Cardiac Surgery of the University of Basel/Switzerland, 4000 Basel/Switzerland. 
having collected the expiratory gas mixture for determination of $\mathrm{PcO}_{2}\left(=\mathrm{PE}_{\mathrm{CO}_{2}}\right)$.

Determinations were made in a consecutive series of 21 patients who were ventilated for more than 24 hours following heart valve replacement and whose pulmonary arterial catheter was patent for more than 24 hours. One patient was operated on in the same period and investigated in the first group but was eliminated from the final report because of atelectasis of a pulmonary lobe accompanied by recurrent pleural effusion requiring paracentesis. In the remaining patients serial chest $\mathrm{X}$-rays were reported to be essentially normal.

In all patients the Mark VIII Bird ventilator was adjusted to meet the following specifications: tidal volume $15 \mathrm{ml} / \mathrm{kg}$ (Wright respirometer); the respiratory rate was adjusted to maintain arterial $\mathrm{PcO}_{2}$ between 37 and $43 \mathrm{~mm} \mathrm{Hg}$; time of expiration was twice as long as time of inspiration. This brought the inspiration rate approximately to 8 b.p.m., and the end-inspiratory pressure to $18-30 \mathrm{~cm} \mathrm{H}_{2} \mathrm{O}$. Satisfactory sedation was maintained with repeated intravenous doses of morphine to achieve almost controlled ventilation. Every 30 minutes the inspiratory pressure was increased by $10-15 \mathrm{~cm} \mathrm{H}_{2} \mathrm{O}$ for three respiratory cycles (the so-called deep sigh). The patients' position was regularly changed (1 hour in the left lateral position, 2 hours in the dorsal position, 1 hour in the right lateral position).

In the first 9 patients the Bird ventilator was operated with $100 \%$ oxygen (using the "air-mix" mode) and the measured inspiratory oxygen concentration was $75-95 \%$, averaging $83 \%$ * (see table II). In the next 11 patients, the Bird ventilator was operated with a gas mixture of $40 \%$ oxygen and $60 \%$ nitrogen. $\mathrm{FI}_{\mathrm{O}_{2}}$ was measured daily in each patient using a Beckman analyzer. Intrapulmonary right-to-left shunt was measured in both groups of patients one to four times daily, after ventilation with $100 \%$ oxygen for $20 \mathrm{~min}$. At the end of these test periods blood samples were taken from the pulmonary artery and from the left atrium or the radial artery. Determinations of $\mathrm{PO}_{2}, \mathrm{PcO}_{2}, \mathrm{So}_{2}$ and haemoglobin concentration were also made at this time. Both groups of patients were similar in regard to age, sex, type of operation and severity of cardiac disease (table 1). The preoperative pulmonary arteriolar resistance index exceeded 6 units $/ \mathrm{m}^{2}$ in two patients of the first group and in three of the second group. No patient showed clinical or radio-

* See Fairley and Britt (1964).
TABLE I. Sex, age, classification according to the New York Heart Association and operation of 20 patients postoperatively ventilated.

\begin{tabular}{|c|c|c|c|c|}
\hline \multirow[b]{2}{*}{ No. } & \multirow[b]{2}{*}{ Sex } & \multirow{2}{*}{$\begin{array}{l}\text { Age } \\
\text { (yr) }\end{array}$} & \multirow{2}{*}{$\begin{array}{l}\text { NYHA } \\
\text { classn. }\end{array}$} & Operation \\
\hline & & & & MVR AVR TVR \\
\hline \multicolumn{5}{|c|}{ Group 1} \\
\hline $\begin{array}{l}1 \\
2 \\
3 \\
4 \\
5 \\
6 \\
7 \\
8 \\
9\end{array}$ & $\begin{array}{l}\mathrm{m} \\
\mathbf{f} \\
\mathbf{f} \\
\mathbf{m} \\
\mathrm{m} \\
\mathrm{f} \\
\mathrm{m} \\
\mathrm{m} \\
\mathrm{m}\end{array}$ & $\begin{array}{l}37 \\
49 \\
33 \\
32 \\
29 \\
45 \\
37 \\
44 \\
20\end{array}$ & $\begin{array}{l}\text { III } \\
\text { II } \\
\text { IV } \\
\text { I (SBE) } \\
\text { III } \\
\text { III } \\
\text { III } \\
\text { I (AP) } \\
\text { IV }\end{array}$ & $\begin{array}{r}\text { MVR } \\
\text { MVR } \\
\text { MVR } \\
\text { MCT + AVR } \\
\text { AVR } \\
\text { AVR } \\
\text { AVR } \\
\text { AVR } \\
M V R+A V R\end{array}$ \\
\hline \multicolumn{5}{|c|}{ Group 2} \\
\hline $\begin{array}{l}10 \\
11 \\
12 \\
13 \\
14 \\
15 \\
16 \\
17 \\
18 \\
19 \\
20\end{array}$ & $\begin{array}{c}\mathbf{m} \\
\mathbf{f} \\
\mathbf{f} \\
\mathrm{m} \\
\mathrm{m} \\
\mathbf{m} \\
\mathbf{f} \\
\mathrm{f} \\
\mathrm{m} \\
\mathrm{m}\end{array}$ & $\begin{array}{l}56 \\
23 \\
64 \\
29 \\
53 \\
52 \\
54 \\
46 \\
18 \\
32 \\
46\end{array}$ & $\begin{array}{l}\text { III } \\
\text { IV } \\
\text { III } \\
\text { II } \\
\text { III } \\
\text { II } \\
\text { IV } \\
\text { IV } \\
\text { II } \\
\text { I (SBE) } \\
\text { II }\end{array}$ & $\begin{array}{c}\text { MVR } \\
\text { MVR } \\
\text { MVR } \\
\text { AVR } \\
\text { AVR } \\
\text { MVR+AVR } \\
\text { MVR+AVR+TVR }+ \text { AVR } \\
\text { MVR+ AVR + TVR } \\
\text { AVR } \\
\text { AVR } \\
\text { AVR }\end{array}$ \\
\hline
\end{tabular}

MVR=mitral valve replacement.

AVR = aortic valve replacement.

TVR = tricuspid valve replacement.

MCT $=$ mitral commissurotomy.

SBE = subacute bacterial endocarditis.

$\mathrm{AP}=$ angina pectoris.

logical (in daily X-rays) evidence of pulmonary infection. Daily bacteriological controls of tracheobronchial secretions showed no positive cultures in any patient on the first operative day. On the second day there was one positive culture (Pseudomonas) in group 1 and two positive cultures (Pseudomonas, Klebsiella resp.) in group 2 . In each group there was one death during the first four postoperative weeks.

\section{RESULTS}

The results are presented in figure 1 and table II. Both groups showed an increased intrapulmonary right-to-left shunt within the first 24 hours, but the two groups clearly differed in the extent of this increase. The contribution of the right-to-left shunted blood to the total cardiac output (QS/QT) rose from an average initial value for all patients of about $6 \%$ to an average of $15 \%$ after 24 hours and $17 \%$ after 48 hours in the patients ventilated with $83 \%$ oxygen and $9 \%$ in those ventilated with $40 \%$ oxygen. Even the first values, determined within a few hours after the end of the anaesthesia, showed a certain difference between the two groups but with a wide range. After 24 hours of ventilation 
TABLE II. Individual values for arterial oxygen tension and shunt in the patients from the two ventilation groups.

\begin{tabular}{|c|c|c|c|c|c|c|c|}
\hline \multirow[b]{2}{*}{$\begin{array}{c}\text { Patient } \\
\text { No. }\end{array}$} & \multirow[b]{2}{*}{$\mathrm{FIO}_{2}$} & \multicolumn{2}{|c|}{ Day of operation } & \multicolumn{2}{|c|}{ 1st postop. day } & \multicolumn{2}{|c|}{ 2nd postop. day } \\
\hline & & $\underset{(\mathrm{mm} \mathrm{Hg})}{\mathrm{Pao}_{2}}$ & Qs/QT & $\underset{(\mathrm{mm} \mathrm{Hg})}{\mathrm{PaO}_{2}}$ & Q́s/Q́T & $\begin{array}{c}\mathrm{PaO}_{2} \\
(\mathrm{~mm} \mathrm{Hg})\end{array}$ & Q́s/Q́T \\
\hline 1 & 0.75 & $\begin{array}{l}333 \\
255\end{array}$ & $\begin{array}{r}9.85 \\
19.55\end{array}$ & $\begin{array}{l}310 \\
228\end{array}$ & $\begin{array}{l}16.1 \\
16.9\end{array}$ & 222 & 18.6 \\
\hline 2 & 0.94 & 400 & $*$ & 265 & 14.25 & & \\
\hline 3 & 0.88 & 498 & 8.35 & $\begin{array}{l}420 \\
415 \\
293\end{array}$ & $\begin{array}{l}14.1 \\
14.6 \\
14.0\end{array}$ & & \\
\hline 4 & 0.95 & 430 & $*$ & 293 & 14.0 & & \\
\hline 5 & 0.75 & 505 & 4.96 & $\begin{array}{l}425 \\
345 \\
250\end{array}$ & $\begin{array}{l}12.5 \\
15.35 \\
15.6\end{array}$ & & \\
\hline 6 & 0.75 & 247 & 15.7 & 200 & 17.3 & $\begin{array}{l}169 \\
115\end{array}$ & $\begin{array}{l}23.8 \\
21.4\end{array}$ \\
\hline 7 & 0.82 & 350 & * & 255 & 19.8 & & \\
\hline 8 & 0.82 & 360 & 11.15 & $\begin{array}{l}192 \\
234\end{array}$ & $\begin{array}{l}17.1 \\
14.5 \\
14.5\end{array}$ & $\begin{array}{l}93.5 \\
220 \\
235\end{array}$ & $\begin{array}{l}17.7 \\
15.1 \\
14.1\end{array}$ \\
\hline 9 & 0.80 & 430 & 8.85 & 350 & 12.7 & 390 & 12.1 \\
\hline $\begin{array}{l}\text { Mean } \\
\text { SD } \\
\end{array}$ & 0.83 & $\begin{array}{r}381 \\
+89 \\
\end{array}$ & $\begin{array}{r}11.2 \\
\pm 4.9 \\
\end{array}$ & $\begin{array}{r}290 \\
\pm 80 \\
\end{array}$ & $\begin{array}{r}15.3 \\
\pm 2.1 \\
\end{array}$ & $\begin{array}{r}207 \\
\pm 97 \\
\end{array}$ & $\begin{array}{r}17.5 \\
\pm 4.3 \\
\end{array}$ \\
\hline $\begin{array}{l}10 \\
11\end{array}$ & $\begin{array}{l}0.4 \\
0.4\end{array}$ & $\begin{array}{l}400 \\
472\end{array}$ & $\begin{array}{l}6.5 \\
8.05\end{array}$ & $\begin{array}{l}407 \\
455 \\
465 \\
405\end{array}$ & $\begin{array}{c}11.65 \\
5.1 \\
5.72 \\
7.1\end{array}$ & 400 & 9.48 \\
\hline 12 & 0.4 & $\begin{array}{l}355 \\
420\end{array}$ & $\begin{array}{l}8.3 \\
8.81\end{array}$ & $\begin{array}{l}410 \\
415\end{array}$ & $\begin{array}{l}9.9 \\
8.85\end{array}$ & $\begin{array}{l}375 \\
335\end{array}$ & $\begin{array}{r}9.07 \\
10.07\end{array}$ \\
\hline 13 & 0.4 & 465 & 7.6 & $\begin{array}{l}420 \\
425\end{array}$ & $\begin{array}{l}8.9 \\
8.48\end{array}$ & & \\
\hline 14 & 0.4 & 405 & 8.75 & 440 & 11.6 & $\begin{array}{l}390 \\
380 \\
470\end{array}$ & $\begin{array}{l}8.1 \\
9.97 \\
7.52\end{array}$ \\
\hline 15 & 0.4 & $\begin{array}{l}395 \\
415\end{array}$ & $\begin{array}{l}7.57 \\
8.36\end{array}$ & $\begin{array}{l}345 \\
350\end{array}$ & $\begin{array}{l}12.25 \\
12.49\end{array}$ & $\begin{array}{l}390 \\
425\end{array}$ & $\begin{array}{r}10.45 \\
8.32\end{array}$ \\
\hline 16 & 0.4 & $\begin{array}{l}430 \\
440\end{array}$ & $\begin{array}{l}8.0 \\
8.8\end{array}$ & $\begin{array}{l}440 \\
420\end{array}$ & $\begin{array}{l}9.37 \\
8.95\end{array}$ & 415 & 8.17 \\
\hline 17 & 0.4 & 360 & 9.5 & $\begin{array}{l}375 \\
360\end{array}$ & $\begin{array}{l}10.55 \\
12.5\end{array}$ & & \\
\hline 18 & 0.4 & 534 & 4.25 & $\begin{array}{l}485 \\
490\end{array}$ & $\begin{array}{l}7.15 \\
7.3\end{array}$ & 435 & 9.9 \\
\hline $\begin{array}{l}19 \\
20\end{array}$ & $\begin{array}{l}0.4 \\
0.4\end{array}$ & $\begin{array}{l}452 \\
450\end{array}$ & $\begin{array}{l}7.27 \\
9.2\end{array}$ & $\begin{array}{l}427 \\
404 \\
412\end{array}$ & $\begin{array}{l}10.38 \\
11.03 \\
10.79\end{array}$ & 445 & 11.2 \\
\hline $\begin{array}{l}\text { Mean } \\
\text { SD }\end{array}$ & 0.4 & $\begin{array}{c}428 \\
\pm 47.1\end{array}$ & $\begin{array}{r}7.9 \\
+1.4\end{array}$ & $\begin{array}{r}417.5 \\
\pm 39.8\end{array}$ & $\begin{array}{r}9.5 \\
+2.21 \\
\end{array}$ & $\begin{array}{c}405 \\
\pm 37.6 \\
\end{array}$ & $\begin{array}{l}9.29 \\
+1.2 \\
\end{array}$ \\
\hline
\end{tabular}

* Pulmonary arterial oxygen saturation not available.

the difference was statistically significant $(P<0.001)$. The $V D / V T$ showed a wide range in both groups. The average in the group ventilated with the high oxygen concentration was $0.563( \pm 0.060)$ and, in the group ventilated with $40 \%$ oxygen, 0.546 $( \pm 0.066)$. There was no statistically significant difference between the two groups.

\section{DISCUSSION}

These results indicate that postoperative controlled ventilation with a high inspired oxygen concentra- tion is prone to increase intrapulmonary right-toleft shunt when compared with ventilation with $40 \%$ oxygen.

In normal volunteers breathing spontaneously Van de Water and associates (1970) could not find an influence of high inspired oxygen concentration on intrapulmonary right-to-left shunt after about 12 hours. These results should not be compared with those from ventilated patients.

In an investigation similar to the present Singer and associates (1970) did not find any increase in 

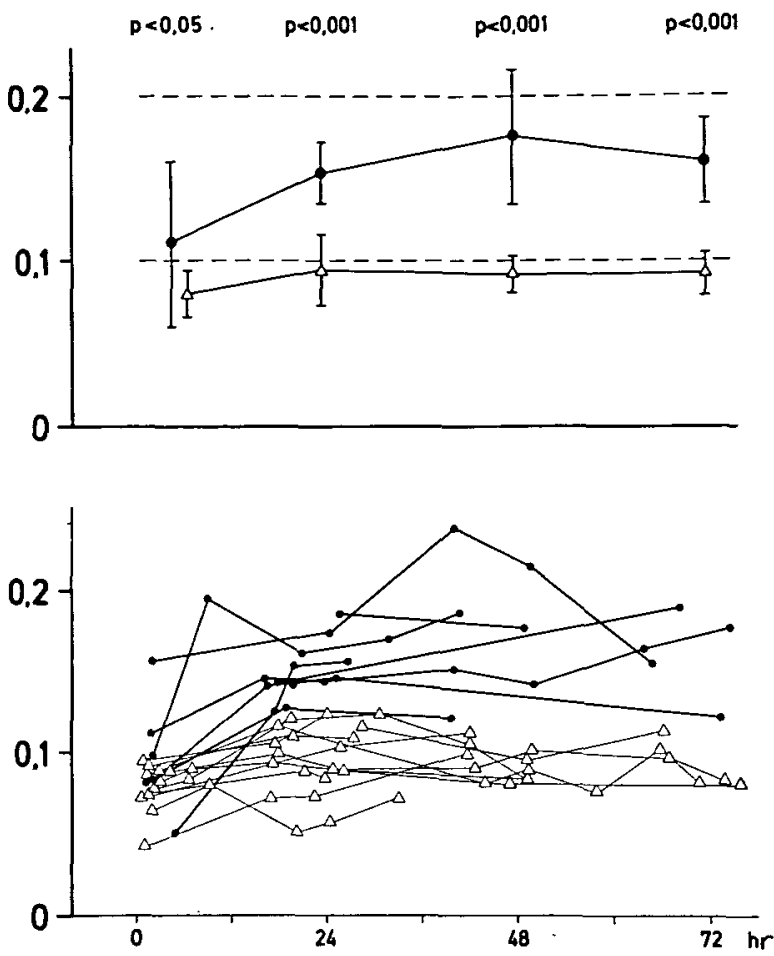

FIG. 1. Intrapulmonary right-to-left shunt (Qs/QT) in 20 patients during postoperative ventilation. Individual values below and mean values with SD above.

Time $0=$ end of anaesthesia.

$\triangle$ Average $\mathrm{FI}_{2}=0.4(n=11)$.

Average $\mathrm{FI}_{\mathrm{O}_{2}}=0.83(n=9)$.

For Qs/QT determination, all patients were ventilated with $100 \%$ oxygen for $20 \mathrm{~min}$.

$P$ values refer to significance of the differences between mean values of the two groups at time indicated.

intrapulmonary right-to-left shunt when using high concentrations of inspired oxygen. But some details in their technique are different from ours. First: in an unknown number of their patients the venous blood was sampled from the right atrium and not from the pulmonary artery. In a series of 12 patients we compared the venous oxygen content of blood sampled simultaneously from the right atrium and from the pulmonary artery. They differed up to 4 vol $\%$ in both directions and the difference changed sometimes in the same patient from hour to hour by more than $3 \mathrm{vol} \%$. Second: in the series of Singer and associates the venous oxygen content was determined from the oxygen tension, $\mathrm{pH}$ and temperature with the use of standard dissociation curves. In our study venous oxygen saturation was measured directly. It is very likely that in these situations the oxygen dissociation curve is not normal. Third: the tidal volume was $10-15 \mathrm{ml} / \mathrm{kg}$ (in ours $15 \mathrm{ml} / \mathrm{kg}$ ) and the $\mathrm{Pa}_{\mathrm{CO}_{2}} 30-40 \mathrm{~mm} \mathrm{Hg}$ (in ours $37-43 \mathrm{~mm} \mathrm{Hg}$ ). Therefore their patients were ventilated at a higher rate than those in the present study. Perhaps they had more "assisted" than "controlled" ventilation. This implies that we administered probably more morphine than did Singer and associates.

For these reasons the two series cannot be directly compared. The differing results are not necessarily incompatible.

Barber, Lee and Hamilton (1970) found a significant increase of the intrapulmonary right-to-left shunt in patients who had suffered irreversible brain damage if they were ventilated with pure oxygen. In this study the venous blood was sampled from the pulmonary artery.

Considering all these results one cannot exclude the possibility that prolonged artificial ventilation with high inspiratory oxygen concentration may adversely affect pulmonary function by increasing the intrapulmonary right-to-left shunt. Further prospective studies are required to determine the exact conditions in which oxygen has this adverse effect.

\section{REFERENCES}

Barber, R. E., Lee, J. and Hamilton, W. K. (1970). Oxygen toxicity in man. N. Engl. F. Med., 283, 1478.

Fairley, H. B., and Britt, B. A. (1964). The adequacy of the air-mix control in ventilators operated from an oxygen source. Canad. Med. Ass. 7., 90, 1394.

Laver, M. B. (1970). The oxygen dilemma: from lungs to hemoglobin. Anesthesiology, 32, 1.

Nash, G., Blennerhassett, J. B., and Pontoppidan, $\boldsymbol{H}$. (1967). Pulmonary lesions associated with oxygen therapy and artificial ventilation. N. Engl. 7 . Med., 276, 368.

Rahn, H., and Farhi, L. B. (1964). Ventilation, perfusion and gas exchange-the $\dot{V a} / Q$ concept; in Field, J., Handbook of Physiology; Section 3, Respiration. Washington, D.C.: American Physiological Society, 1, 735.

Singer, M. M., Wright, F., Stanley, L. K., Roe, B. B., and Hamilton, W. K., (1970). Oxygen toxicity in man. $N$. Engl. F. Med., 283, 1473.

Van de Water, J. M., Kagey, K. S., Miller, I. T., Parker, D. A., O'Connor, N. E., Sheh, J. M., McArthur, J. D., Zollinger, R. M. jr, and Moore, F. D. (1970). Response of the lung to 6 to 12 hours of 100 per cent oxygen inhalation in normal man. N. Engl. F. Med., 283, 621.

\section{EFFETS EXERCES PAR LA CONCENTRATION D'OXYGENE INSPIRE SUR LE SHUNT DROIT- \\ GAUCHE INTRAPULMONAIRE AU COURS D'UNE RESPIRATION ASSISTEE POST-OPERATOIRE}

\section{SOMMAIRE}

Une série entière de malades devant subir une intervention de chirurgie cardiaque pour plastie valvulaire, a été répartie en deux groupes. Le premier groupe a été soumis à une respiration assistée post-opératoire en utilisant le respirateur de Bird à oxygène. La concentration inspiratoire d'oxygène a été de $83 \%$. Dans le second groupe, on a également eu 
recours à un respirateur de Bird, mais avec une concentration d'oxygène de $40 \%$ seulement. Dans le premier groupe, le shunt intrapulmonaire droit-gauche a accusé une augmentation jusqu'à un chiffre moyen de $17 \%$ au cours des deux premiers jours ayant suivi l'intervention et dans le second groupe, jusqu'à une moyenne de. $9 \%$. Cette étude est en faveur du point de vue selon lequel la concentration inspiratoire d'oxygène devrait être maintenue à un taux suffisamment élevé afin de parvenir à une saturation normale en oxygène du sang artériel.

\section{WIRKUNG EINER EINGEATMETEN SAUERSTOFFKONZENTRATION AUF DEN INTRAPULMONALEN RECHTS-LINKS-SHUNT IN DER POSTOPERATIVEN PHASE MIT MECHANISCHER BEATMUNG}

\section{ZUSAMMENFASSUNG}

Eine konsekutive Serie von Patienten nach operativem Herzklappenersatz wurde in 2 Gruppen geteilt. Die erste Gruppe wurde postoperativ mit dem sauerstoffbetriebenen Bird-Respirator beatmet. Die inspiratorische Sauerstoffkonzentration betrug im Mittel $83 \%$. Auch die zweite Gruppe wurde mit dem Bird-Respirator beatmet, aber mit einer inspiratorischen Sauerstoffkonzentration von genau $40 \%$. In der ersten Gruppe stieg der intrapulmonale Rechts-Links-Shunt auf einen durchschnittlichen Wert von $17 \%$ in den ersten 2 postoperativen Tagen, während der intrapulmonale Rechts-Links-Shunt in der zweiten Gruppe nur auf $9 \%$ anstieg. Die Untersuchung bestätigt die Taktik, die inspiratorische Sauerstoffkonzentration nur gerade so hoch einzustellen, baß noch normale arterielle Sättigung gewährleistet ist.

\section{EL EFECTO DE LA CONCENTRACION DE OXIGENO INSPIRADO SOBRE EL SHUNT INTRAPULMONAR DERECHA A IZQUIERDA DURANTE LA VENTILACION MECANICA POSOPERATORIA}

\section{RESUMEN}

Una serie consecutiva de pacientes sometidos a cirugía cardíaca para reemplazamiento valvular fue dividida en dos grupos. El primero fue sometido a ventilación artificial posoperatoria utilizando el ventilador de Bird accionado por oxígeno. La concentración de oxígeno inspiratorio fue del 83 por ciento. En el segundo grupo también fue usado un ventilador Bird con una concentración de oxígeno del 40 por ciento. En el primer grupo, el shunt intrapulmonar derecha a izuierda aumentó hasta un promedio del 17 por ciento durante los dos primeros días posoperatorios y en el segundo grupo hasta un promedio del 9 por ciento. Este estudio apoya la opinión de que la concentración de oxígeno inspiratorio deberá ser conservada solamente lo bastante elevada para conseguir una saturación normal de oxígeno en la sangre arterial.

\section{BOOK REVIEW}

Proceedings of the Fourth International Congress on Hyperbaric Medicine. Edited by J. Wada and T. Iwa. Published by Igaku Shoin Ltd, Tokyo (Published in U.K. by Baillière Tindall and Cassell), 1970. Pp. 545; illustrated; indexed. Price $£ 15$.

It is exactly ten years since the medical world was entering one of its cycles of enthusiasm for hyperbaric oxygen. It had happened before, in the nineteenth century and the 1920 s. However, this time it was going to be different: the sophistication of measurement technology would bring a precision in judgement which would assess progress unequivocally. Moreover, priorities in medicine had changed; the hypoxic diseases were now at the forefront of thinking. The concept of forcing the required amount of oxygen into arterial bloood appeared both simple and logical. It couldn't fail.

But nature rebelled in favour of conditions which, most often, came very close to those existing before treatment. In nearly every organ it could be demonstrated that blood flow reduced as the oxygen inflow increased. It was argued, of course, that at the cellular level, in ischaemic areas, this might not be so. This could be, and was, determined more usefully by clinical trials. One by one, these had disappointing results. The applications in cardiac surgery were watered down by qualified disappointments from results together with improved alternative technology. The therapeutic failures were accompanied by significant risks from oxygen toxicity. Decompression disorders of the nervous system, lung and bones had to be reckoned with by personnel and air-filled chambers and at least one team (in Japan) met with personal disaster from a fire in high pressure oxygen.

In the United Kingdom, the entire phenomenon met with commendable sobriety. Support for evaluation was vested in centres where enthusiasm could be tempered by scientific objectivity and consequently a fair assessment of prospects was achieved with minimum cost in time, effort and money. The bulk of the valid scientific clinical studies has emanated from these and various American centres.

Held against this general background, the Fourth International Congress, in Japan in 1969, could not have been expected to be an occasion for unqualified rejoicing. The Proceedings reflect this. On the other hand, the field of hyperbaric medicine has stimulated much high quality investigation and there is some sound applied physiology within this book. Of special note are studies on pulmonary oxygen toxicity and the studies of the effect of hyperoxia on the cardiovascular system. The findings in the latter are in support of the general rule cited above. Despite several contributions on the subject, it is distressing to find a persistent failure to evaluate objectively the role of hyperbaric oxygen in the management of gas gangrene. This remains one of the important unknowns.

The Congress was not entirely devoid of enthusiasts; a few turned up. They can be identified by their practice of publishing photographs of their pressure chambers and their obvious good fortune in managing a wide variety of diseases.

At $£ 15$ this book will not be popular with budgetconscious librarians. However, it deserves a place in large libraries and anaesthetists with a special interest in the subiect will find much to refer to.

The next Congress is scheduled for 1973, although, from the clinical standpoint, the party's nearly over, Owners of pressure chambers should not forget that, on present form, the next resurgence will be about the turn of the century. Alastair A. Spence 